\title{
Pensononowoor
}

2017 , vol. $77,45-57$

http://dx.doi.org/10.12657/denbio.077.004

\author{
Jarostaw Socha, Wojciech Ochat
}

\section{Dynamic site index model and trends in changes of site productivity for Alnus glutinosa (L.) Gaertn. in southern Poland}

Received: 16 May 2016; Accepted: 10 October 2016

\begin{abstract}
Black alder is naturally widespread across all of Europe and has an increasing importance for forest ecosystems. Thanks to the considerable tolerance to adverse climatic and edaphic environmental conditions black alder is important both in open landscapes and can also be involved in the rehabilitation of disturbed soils. Assessment of site productivity is essential for providing a frame of reference for silvicultural diagnosis and prescription in order to ensure the sustainability of existing and newly established ecosystems. The most accepted method of evaluating site productivity is the site index (SI). The aim of the presented research was to develop the SI model for black alder in southern Poland. The developed SI model was used as a tool in order to test the research hypothesis assuming the increase in site productivity for black alder in southern Poland. The research material for development of SI model were stem analysis data from 180 research plots. Both, the local model parameter, which was estimated individually for every tree, and the other parameters estimated globally for the whole data set were estimated simultaneously. Changes in site productivity were analyzed on research plots and a set of 12,974 stands from the forest inventory database. Site indices calculated using the developed model are negatively correlated with age/ positively correlated with establishment year of the stands. This confirms the existence of the phenomenon of increasing site productivity for black alder. During the last century site productivity measured with site index increased on average $5 \mathrm{~m}$. Therefore, black alder that belongs to the fast-growing tree species should be considered of the increasing importance for forest management.
\end{abstract}

Keywords: height growth model, height-age relationship, forest site, evaluating site productivity, alder

Addresses: J. Socha, Department of Biometry and Forest Productivity, Faculty of Forestry, University of Agriculture in Krakow, al. 29 Listopada 46, 31-425 Kraków, e-mail: rlsocha@cyf-kr.edu.pl W. Ochał, Department of Biometry and Forest Productivity, Faculty of Forestry, University of Agriculture in Krakow, al. 29 Listopada 46, 31-425 Kraków, e-mail: rlochal@cyf-kr.edu.pl

\section{Introduction}

Black alder (Alnus glutinosa (L.) Gaertn.) is naturally widespread across all of Europe, i.e., from
mid-Scandinavia to the Mediterranean countries (Claessens et al., 2010). In North Central Europe (Netherlands, Northern Germany, and the Baltic States) and South Central Europe (the plains of 
Slovenia and Croatia), black alder represents $\sim 5 \%$ of the forest area and forms large highly productive stands (Glavac, 1972; Roisin \& Thill, 1972; Turok et al., 1996; Claessens et al., 2010). Black alder belongs to fast-growing tree species of an increasing importance, especially in Central and Northern Europe (Johansson, 1999; Uri et al., 2014; Hytönen \& Saarsalmi, 2015; Vacek et al., 2016). Despite being one of the most common species in the first generation stands established by natural regeneration on more fertile sites, black alder has an increasing importance and large potential for timber production (Claessens et al., 2010). Alder wood is light, soft, and water resistant. It is used for the production of furniture, fences, and objects exposed to permanent contact with water. It can also be used as fuel. Nevertheless, the production of high-quality black alder timber is only possible on the sites that correspond closely to its autecological optimum, as with other valuable tree species (Thill \& Mathy, 1980; Thibaut et al., 2004). Outside the forest, black alder is important in open landscapes, especially in linear stands along stream and river banks. Thanks to the considerable tolerance to adverse climatic and edaphic environmental conditions alder can also be involved in the rehabilitation of disturbed soils (Krzaklewski et al., 2012). In Poland, black alder covers 5.5\% (504,249 ha) of the forest area (www.bdl.lasy.gov.pl, 2015) and is one of the seven most important forest-forming tree species.

The information concerning the potential site productivity is crucial in order to ensure the sustainability of existing and newly established black alder ecosystems. Site productivity constitutes the basic criterion considered for site-specific decisions concerning the planning of silvicultural treatments, determining allowable cut and rotation period and forecasting timber yield (Chen et al., 1998; Socha, 2008; Splechtna, 2001).

The most commonly used and widely accepted method of evaluating site productivity is the site index (Johansson, 1999; Raulier et al., 2003; Skovsgaard \& Vanclay, 2008) determined on the basis of the height of a stand at a certain age using species-specific site index models, which are also the primary modules in the growth models of trees and stands (Hägglund, 1981; Pretzsch et al., 2002; Pretzsch, 2009; Bruchwald \& Zasada, 2010).

Climate change will affect forest site productivity and will result in change of growth rates, the rate of ecosystem processes, and the ability to carry out forest operations. Therefore, the actions and strategies for adaptation of the forest management system are necessary, that consider current climate, projected climate change impacts and related forest vulnerabilities. Site index can be used as a tool to understand the effect of changing climate on the forest growth.
One of the indicators of changes in site conditions is an age trend manifested by a negative correlation between site index and stands' age or positive correlation between site index and stand origin (year), which have been frequently reported (Albert \& Schmidt, 2010; Elfving \& Tegnhammar, 1996; Nothdurft et al., 2012; Sharma et al., 2012; Socha et al., 2016; Solberg et al., 2009; Yue et al., 2014).

Forest site productivity remains a fundamental variable in forestry (Bontemps \& Bouriaud, 2013); however, in order to estimate the site productivity for the given tree species, there is a need for a site index model, which sufficiently characterizes site productivity and therefore could be useful in both forest research and management (Skovsgaard \& Vanclay, 2008). Therefore, the construction of site index models is a fundamental task for site quality differentiation (Palahi et al., 2004) and forest site productivity assessment (Elfving \& Kiviste, 1997). The accuracy in determining the site index in the given site conditions depends on the appropriateness of the site index model, which could be achieved by developing local site index models.

Despite of evident inappropriateness resulted among others from different site conditions and changes in growth dynamics, both in forest management and forestry research in Poland, site productivity for black alder is still determined on the basis of yield Tables by Schwappach (1943) and Tiurin (Szymkiewicz, 2001). To reliably determine the site productivity of black alder, it is necessary to develop a height growth model adapted to local site conditions. The aim of the presented research was to develop the site index model for black alder in southern Poland. The developed model was used as a tool in order to test the research hypothesis assuming the increase in site productivity for black alder in southern Poland.

\section{Materials and Methods}

The study material consists of stem analysis data of dominant and codominant trees as selected from 180 research plots established in even-aged pure black alder stands located in western part of Sandomierz Basin in southern part of Poland (Fig. 1). The stands were randomly chosen from PGL LP (The State Forests National Forest Holding) computer database and they represent a wide range of site conditions - from bog mixed coniferous forest to alder-ash forest. Before selecting the stands the database was filtered using the following criteria: the share of alder above $80 \%$ and the area of a stand larger than 1 ha. In each of the selected stands, three systematically placed circular sample plots were established. Depending on the age and density of a stand the area of 


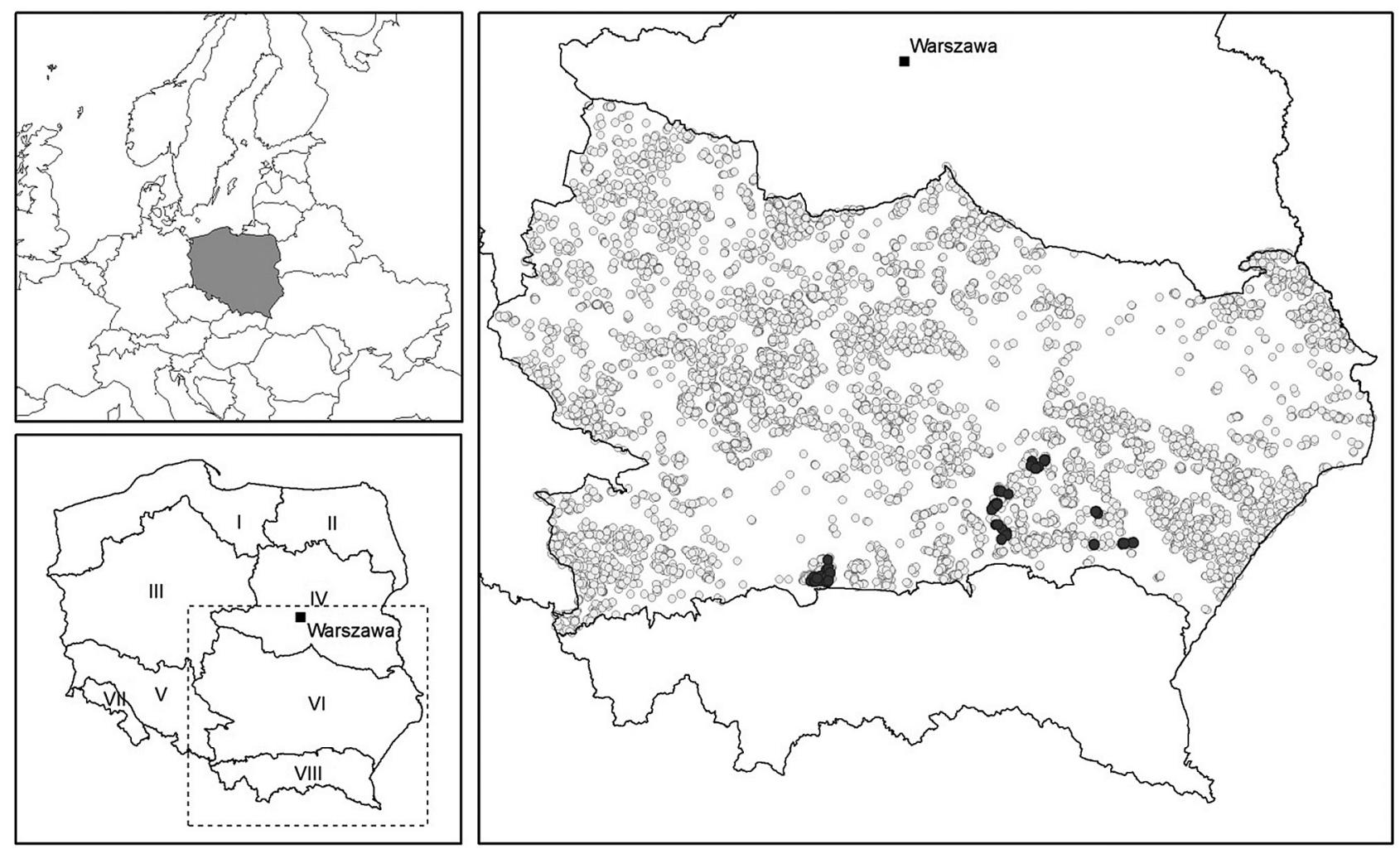

Fig. 1. Location of the research stands (black dots) and stands from the forest inventory database (gray dots) on the area of Małopolska natural-forest region

sample plot varied from 0.01 to 0.10 ha and in every stand it was estimated in order to obtain about 30 trees on the plot. On each sample plot one dominant or codominant tree located nearest to the plot centre, without observable damage, was felled for stem analysis. For trees with trunk length greater than $20 \mathrm{~m}$, disks were cut at stump base $0.5 \mathrm{~m}, 1.3 \mathrm{~m}$, and 2.0 $\mathrm{m}$ above the ground, and then equally spaced disks at $2.0 \mathrm{~m}$ intervals were taken to the top. For trees with smaller trunk length disks were cut out from stump base, $1.3 \mathrm{~m}$ and from the middle of 10 equal length sections. Width and number of annual rings on cross-sectional disks were measured in four radii by using BIOtronik BEPD-5 instrument. Before measuring the discs were smoothed with a scalpel and the counted radii were saturated with water in order to improve the visibility of individual rings.

The course of growth of the individual trees was reconstructed on the basis of the height of the disks and the number of annual rings. As cross-sectional lengths do not coincide with periodic height growth, height-age data from stem analysis were corrected using Carmean's method (Carmean, 1972). The height growth curve of every sampled tree was visually examined for errors in data as well as patterns of suppression, release, and growth anomalies. After carrying out verification, the study material consisted of growth series of 180 black alder trees (Fig. 2). The age of selected trees varied from 7 to 96 years with the heights varying from 15.6 to $31.8 \mathrm{~m}$ (Table $1)$.

Due to the large number of available height growth and site index functions in the literature, the research carried out did not include new model's development, but rather focused on identifying from the pre-existing solutions those, that best describe the height growth of collected alder trees. When selecting a potential model, an assumption was made that the site index model should be characterized by the following properties:

- good fit in the modeled curves to empirical data,

- polymorphism, which would take into account the possible differences in growth patterns, resulting from variability in site conditions,

- variable asymptotes for different sites,

- equality of the site index and height at a certain base age,

- the possibility of using the same function as a height growth and site index model,

- the possibility of biological interpretation of the parameters of the equation.

Because of this, the final form of the site index model depends not only on the assumed growth function, based on which it is developed, but also to a large extent on the result of the method used in the estimation of the parameters. Most of the labor-intensive analysis concerned with the selection of the growth function, and optimal method for the calculation of their parameters. 

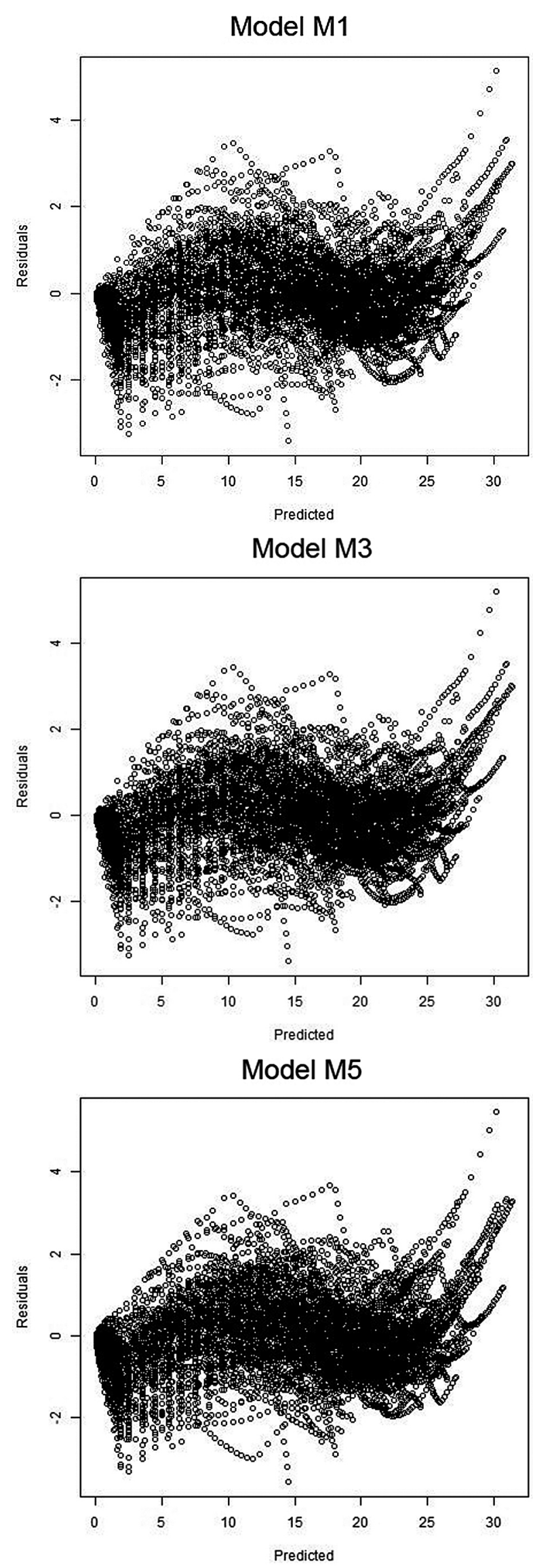
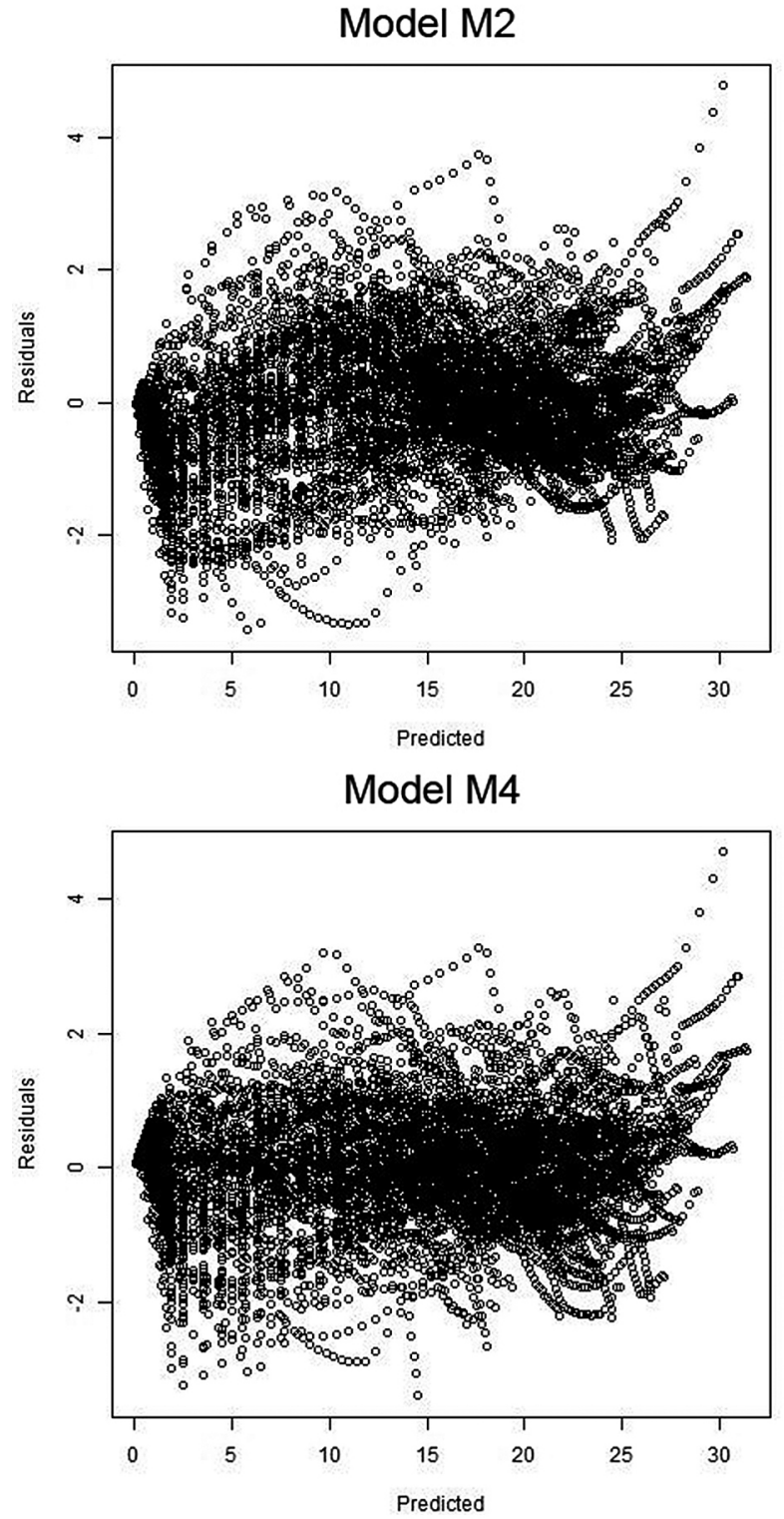

Fig. 2. Scatter plot of residual values against values predicted from models M1 to M5 
Table 1. Mean and range (in parentheses) of the basic characteristics of black alder (Alnus glutinosa (L.) Gaertn.) stands and sample trees

\begin{tabular}{|c|c|c|c|c|c|c|c|c|}
\hline \multicolumn{6}{|c|}{ Black alder stands } & \multicolumn{3}{|c|}{ Sample trees } \\
\hline $\begin{array}{l}\text { Age } \\
\text { class }\end{array}$ & $\begin{array}{l}\text { No of } \\
\text { stands }\end{array}$ & $\begin{array}{c}\text { Age } \\
\text { (years) }\end{array}$ & $\begin{array}{l}\text { No of trees } \\
\left(\text { trees ha }^{-1}\right)\end{array}$ & $\begin{array}{c}g \\
(\mathrm{~cm})\end{array}$ & $\begin{array}{l}\mathrm{TH} \\
(\mathrm{m})\end{array}$ & $\begin{array}{l}\text { No of } \\
\text { trees }\end{array}$ & $\begin{array}{l}d b h \\
(\mathrm{~cm})\end{array}$ & $\begin{array}{c}h \\
(\mathrm{~m})\end{array}$ \\
\hline I & 14 & $\begin{array}{c}12 \\
(7-16)\end{array}$ & $\begin{array}{c}2697 \\
(1200-4360)\end{array}$ & $\begin{array}{c}7.9 \\
(4.5-11.8)\end{array}$ & $\begin{array}{c}11.2 \\
(7.3-16.3)\end{array}$ & 42 & $\begin{array}{c}8.5 \\
(4.0-17.0)\end{array}$ & $\begin{array}{c}9.9 \\
(5.2-16.5)\end{array}$ \\
\hline II & 15 & $\begin{array}{c}29 \\
(21-39)\end{array}$ & $\begin{array}{c}1132 \\
(590-1783)\end{array}$ & $\begin{array}{c}16.2 \\
(10.6-27.4)\end{array}$ & $\begin{array}{c}18.2 \\
(13.2-21.3)\end{array}$ & 45 & $\begin{array}{c}16.8 \\
(11.0-25.5)\end{array}$ & $\begin{array}{c}16.9 \\
(10.6-21.6)\end{array}$ \\
\hline III & 16 & $\begin{array}{c}50 \\
(42-60)\end{array}$ & $\begin{array}{c}540 \\
(272-844)\end{array}$ & $\begin{array}{c}25.6 \\
(18.8-37.0)\end{array}$ & $\begin{array}{c}24 \\
(19.2-26.6)\end{array}$ & 48 & $\begin{array}{c}25.4 \\
(17.2-36.6)\end{array}$ & $\begin{array}{c}22.6 \\
(17.0-27.9)\end{array}$ \\
\hline IV & 10 & $\begin{array}{c}71 \\
(61-79)\end{array}$ & $\begin{array}{c}364 \\
(210-539)\end{array}$ & $\begin{array}{c}33.7 \\
(29.4-39.0)\end{array}$ & $\begin{array}{c}27.0 \\
(23.9-31.0)\end{array}$ & 30 & $\begin{array}{c}35.0 \\
(26.0-44.2)\end{array}$ & $\begin{array}{c}27.0 \\
(22.8-32.1)\end{array}$ \\
\hline $\mathrm{V}$ & 5 & $\begin{array}{c}87 \\
(81-92)\end{array}$ & $\begin{array}{c}361 \\
(230-557)\end{array}$ & $\begin{array}{c}35.0 \\
(27.6-42.7)\end{array}$ & $\begin{array}{c}28.9 \\
(25.7-32.3)\end{array}$ & 15 & $\begin{array}{c}35.3 \\
(24.8-46.7)\end{array}$ & $\begin{array}{c}28.2 \\
(22.8-32.3)\end{array}$ \\
\hline
\end{tabular}

$D g$ - quadratic mean diameter; $T H$ - top height defined as the average height of the 100 largest trees in the stand; $d b h$ - diameter at breast height; $h$ - height

Based on a study of the extensive literature concerning the construction of site index models, five functions were selected for the preliminary analysis, meeting most of the established criteria. The selected functions, denoted with symbols from M1 to M5, in recent years have been successfully applied in site index modeling in a number of forest-forming species, including the black alder (Nord-Larsen, 2006; Nord-Larsen et al., 2009; Socha \& Orzeł, 2013; Socha et al., 2015).

An analysis included following functions:

M1 - a function derived by Cieszewski (2001) based on the Monserud (1984) function as follows:

$$
H_{2}=H_{1} T_{2}^{\beta_{1}}\left(T_{1}^{\beta_{1} R+\beta_{2}}\right) / T_{1}^{\beta_{1}}\left(T_{2}^{\left.\beta_{1} R+\beta_{2}\right)}\right. \text {, }
$$

where

$$
\begin{gathered}
R=Z_{0}+\left(Z_{0}^{2}+2 \beta_{2} H_{1} / T_{1}^{\beta_{1}}\right)^{0,5}, \\
Z_{0}=H_{1}-\beta_{3},
\end{gathered}
$$

$H_{1}$ - height at the age of $T_{1} ; H_{2}$ - height at the age of $T_{2} ; \beta_{i}$ - model parameters.

M2 - a differential equation function derived from Hossfeld's function (Palahí et al., 2004):

$$
H_{2}=T_{2}^{2} /\left(\beta_{1}+T_{2}\left(T_{1} / H_{1}-\beta_{3} \cdot T_{1}-\beta_{1} / T_{1}+\beta_{3} \cdot T_{2}\right)\right)
$$

This equation was used to develop a site index model for Scots pine in north-eastern Spain (Palahí et al., 2004).

M3 - function used for modeling height growth of red alder by Night \& Courtin (1998):

$$
\begin{gathered}
H_{2}=H_{1}\left(1+\exp \left(\beta_{1}-\beta_{2} \log \left(T_{1}\right)-\beta_{3} \cdot \log \left(H_{1}\right)\right)\right) / \\
/\left(1+\exp \left(\beta_{1}-\beta_{2} \log \left(T_{2}\right)-\beta_{3} \cdot \log \left(H_{1}\right)\right)\right)
\end{gathered}
$$

M4 - a function derived from the Korf growth function by Barrio Anta \& Diéguez-Aranda (2005):

$$
H_{2}=\beta_{1}\left(H_{1} / \beta_{1}\right)^{\left(T_{1} / T_{2}\right)^{\beta_{2}}},
$$

M5 - modified Chapman-Richards function (Payandeh, 1974; Cieszewski, 2003):

$$
H_{2}=H_{1}\left(\left(1-\exp \left(\beta_{2} T_{2}\right)\right) /\left(1-\exp \left(\beta_{2} T_{1}\right)\right)\right)^{\wedge}\left(\beta_{3} H_{1}^{\beta_{1}}\right)[5]
$$

The parameters of the selected functions were estimated based on data that were heights of the analyzed trees in particular years of their lives. In fitting the base age invariant site index equations nested iterative procedures were used to fit the global and site-specific parameters (Cieszewski et al., 2000). The procedure began by fitting the global parameters of equations [1] to [5], using the preliminary values of site index $\left(H_{1}\right)$, which were defined based on the mean height at age 50 years estimated for the whole empirical material. In the second step, estimates of the global parameters were used as constants and the site-specific parameter $\left(H_{1}\right)$ was estimated for each tree. Next, the estimated $H_{1}$ values for each tree became the "observed" values and the global parameters were refit. This procedure was repeated until the global parameters stabilized. This iterative procedure was designed and programmed in the $\mathrm{R}$ computer program (R, 2008).

In the case of a data structure representing the repeated measurements of heights of individual trees in subsequent years, within-tree correlation may result in the inefficient estimates and underestimation of standard error. Therefore, the error term $(e)$ was explicitly modeled using a first-order autocorrelation function (Nord-Larsen et al., 2009):

$$
e_{i, T}=p^{\delta t} \cdot \varepsilon_{i, T-\delta t}+\varepsilon_{i}
$$

where

$e_{i, T}-$ is the error at the $i$ th tree at age $T ; \delta t-$ is the time since the previous height observation; $p$ - an autocorrelation between the measurements one year apart; $\varepsilon_{i}$ 
- normally distributed random errors. Second order autocorrelation coefficient was in all cases less than 0.1 and statistically non-significant $(\mathrm{p}<0.05)$.

The selection of the best dynamic growth model was based on statistical criteria, describing the accuracy of the model's fit to empirical data:

- Mean absolute error (MAE)

- Root mean square error (RMSE)

- Adjusted coefficient of determination/model efficiency.

Aside from the statistical measure of the fit properties, the developed models were assessed using graphical analysis of height growth and increment curve fit to empirical data and plots of residuals against the predicted height.

The developed models were also assessed in the light of the reliability of the height increment estimates. Of the five developed site index equations, the selection of the best model was based on the aforementioned criteria.

The best selected site index model was used in the subsequent analysis in order to assess trends in changes of site productivity for black alder in southern Poland. Changes in site productivity for black alder were analyzed based on the relationship between site index and a year of stand origin both for research plots and for the set of 12,974 black alder stands coming from the forest inventory database (www. bdl.lasy.gov.pl, 2015) from Malopolska natural-forest region. Site index was calculated using base age 100 years, which is most commonly applied in European forest research. The relationship between site index and year of the stand origin was described by the linear regression model. The use of site index approach in site productivity assessment is not appropriate to stands at the first phase of establishment because the growth of trees at this stage is mostly dependent on the silvicultural options such as spacing and regeneration method (Skovsgaard \& Vanclay, 2008), moreover in young stands even small height measurement and age determination errors have strong impact on estimated site index (Nigh \& Love, 1999; Zasada, 2002); therefore, in this analysis, research plots and stands from inventory database older than 10 years were used.

\section{Results}

As a result of the parameter estimation of individual growth functions, five dynamic site index models were obtained, which due to the properties of the differential equations are also height growth models (Table 2).

It turned out that based on a consideration of all the assumed statistical criteria for assessing the function fit to empirical data, mean error (MAE), mean square error (RMSE), adjusted coefficient of determination $\left(R_{\text {adj }}^{2}\right)$ were best characterized by the properties of the M4 model (Table 2). Applying models M1, M2, M3 and M5 resulted in an asymmetric dispersion of residuals (Fig. 2). Also values of statistics used in the evaluation of the fit of these models to empirical data were less favorable than in the case of model M4 (Table 2).

Additional information concerning the quality of the representativeness of the model height growth patterns can be obtained by analyzing the graphs of site index curves against the real tree growth series (Fig. 3).

The correctness of the developed models was also evaluated based on an analysis of the usefulness of the designed functions to describe the current annual height increment. This criterion can be considered as an assessment of the biological realism of the developed models. Only in the case of models M3 and M4, according to known regularities, the age of culmination in the growth of height occurred the sooner, the higher the site index was and height increments reached the lower values for the poorer sites (lower site index). In the case of model M1 also demonstrating a very good

Table 2. Parameters of the developed site index models, accuracy of their estimation and the statistics characterizing the fit of the model values to empirical data

\begin{tabular}{|c|c|c|c|c|c|c|}
\hline \multirow{2}{*}{ Site index model } & \multicolumn{3}{|c|}{$\begin{array}{c}\text { Parameter } \\
\text { (Standard error) }\end{array}$} & \multicolumn{3}{|c|}{ Model summary } \\
\hline & $\beta_{1}$ & $\beta_{2}$ & $\beta_{3}$ & $R_{a d j}^{2}$ & RMSE & MAE \\
\hline M1 & $\begin{array}{c}1.6127 \\
(0.0076)\end{array}$ & $\begin{array}{l}1068.91 \\
(164.60)\end{array}$ & $\begin{array}{l}30.50234 \\
(0.37236)\end{array}$ & 0.9875 & 0.922 & 0.6964 \\
\hline M2 & $\begin{array}{c}9.9658 \\
(0.1634)\end{array}$ & - & $\begin{array}{c}0.025080 \\
(0.000167)\end{array}$ & 0.9865 & 0.956 & 0.7182 \\
\hline M3 & $\begin{array}{l}13.4706 \\
(0.1864)\end{array}$ & $\begin{array}{l}1.61221 \\
0.00757)\end{array}$ & $\begin{array}{c}2.56022 \\
(0.05883)\end{array}$ & 0.9875 & 0.921 & 0.6949 \\
\hline M4 & $\begin{array}{l}47.5562 \\
(0.4146)\end{array}$ & $\begin{array}{c}0.70745 \\
(0.00566)\end{array}$ & - & 0.9885 & 0.884 & 0.6633 \\
\hline M5 & $\begin{array}{l}-1.1138 \\
(0.0326)\end{array}$ & $\begin{array}{c}-0.04105 \\
(0.000343)\end{array}$ & $\begin{array}{l}53.62720 \\
(5.56882) \\
\end{array}$ & 0.9860 & 0.974 & 0.7438 \\
\hline
\end{tabular}



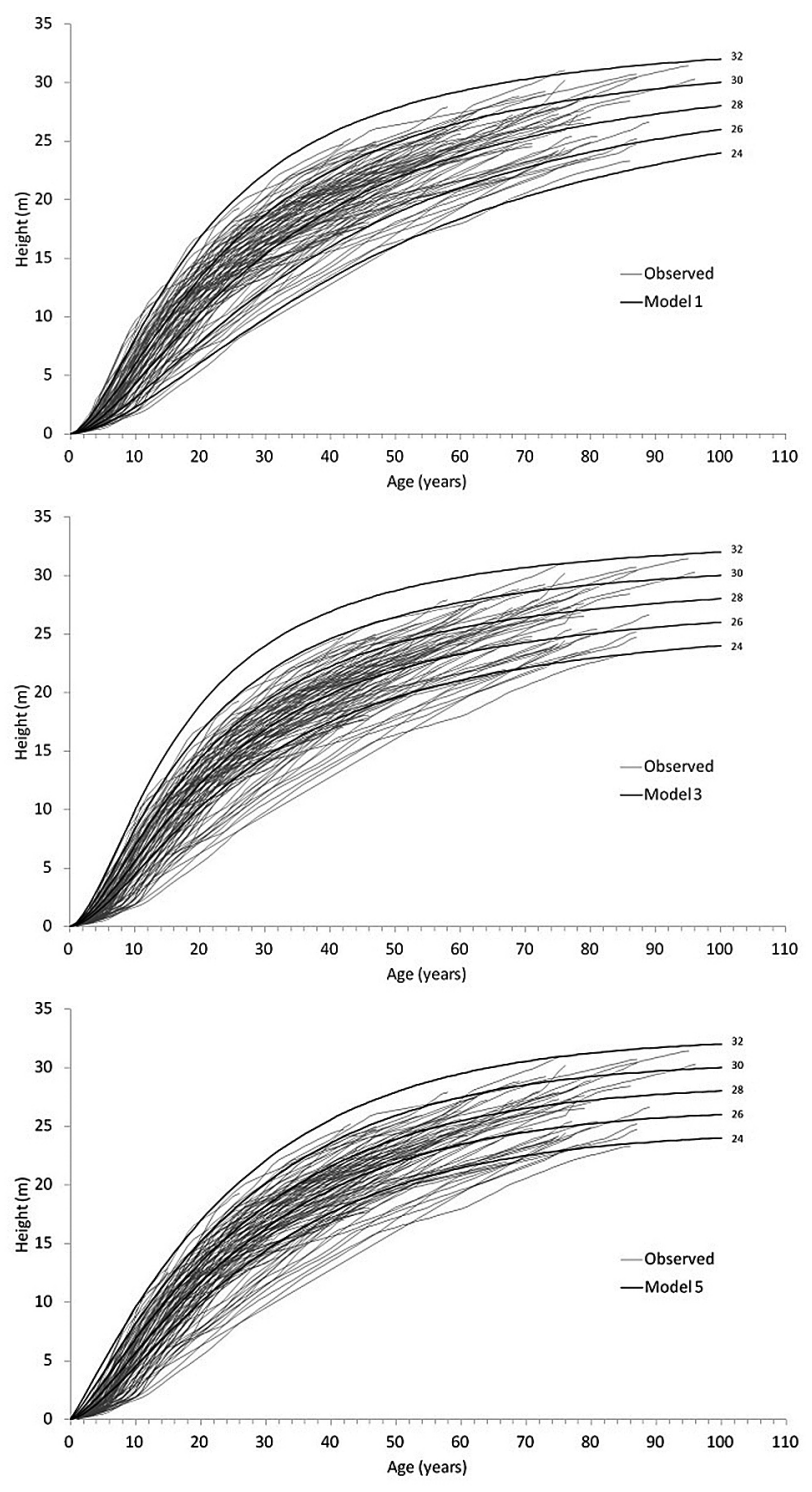

fit to empirical data (Table 2, Fig. 4), for ages above 50 years, height increment calculated for the lower site indices was greater than for the higher site indices. Height increment calculated according to model M2 indicated that the age of culmination of the current height increment occurred the later, the higher was the site index. For the model M4 both the age and value of height increment culmination depended on the site index. For example, for the site index of $24 \mathrm{~m}$, the age of height growth culmination is 18 years, with the value of $0.43 \mathrm{~m}$, and for site index of $34 \mathrm{~m}$ correspondingly 7 years and 1.18 m (Fig. 4).

Site index model M4, with the most desirable characteristics and biological realism, was selected for the subsequent analysis to assess trends in changes of site productivity for black alder in southern Poland.
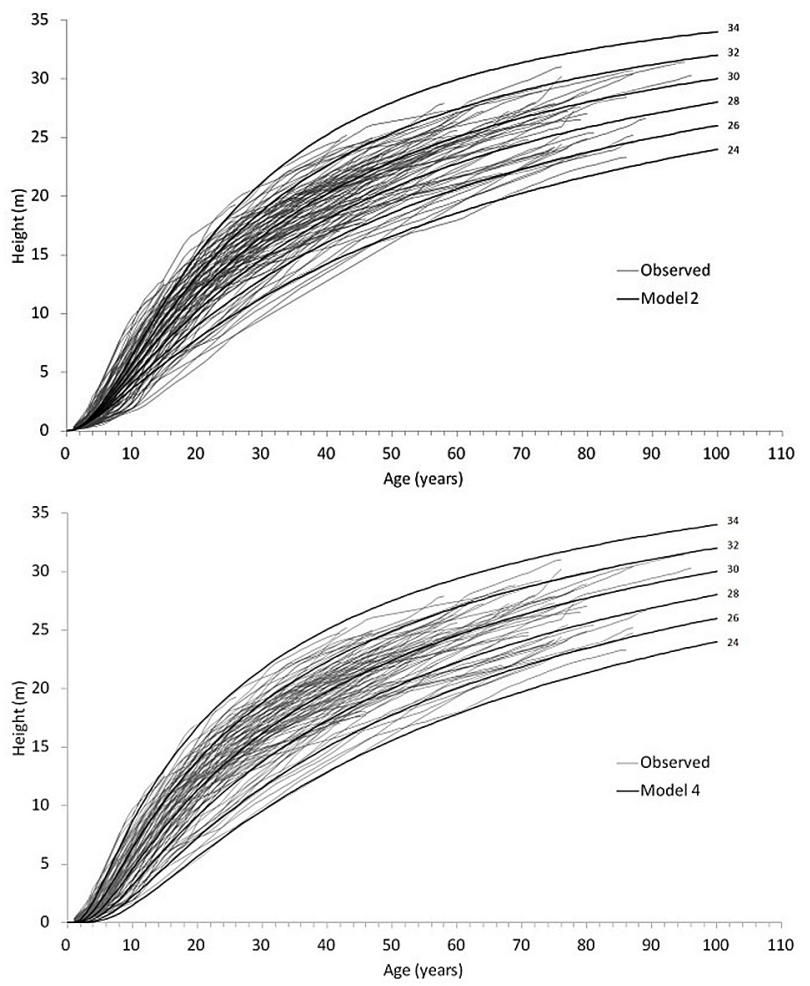

Fig. 3. Site index curves at base age of 100 years drawn for developed site index models 1-5 (black lines) and real growth series of 180 individual trees (gray lines). Numbers refer to height at base age 100 years

It was found that site parameters of individual research plots calculated using the best selected model M4 were significantly positively $(p<0.001)$ correlated with the year of stand establishment, which explained $34.8 \%$ of the site index variability (Fig. 5). The correlation between the site index and stand age indicates the increasing site productivity for black alder; however, it also could be the result of selection of research plots. Highly productive stands are usually managed under short rotation, and consequently older stands may be over-represented on infertile sites, since they require a longer time to reach a certain goal of wood production which also can cause an age trend in site index (Tegnhammar, 1992; Nothdurft et al., 2012; Yue et al., 2014; Socha et al., 2016). Therefore, in order to test the age trend in site index at the larger scale, the data from inventory database of natural-forest region Malopolska were used. We also 

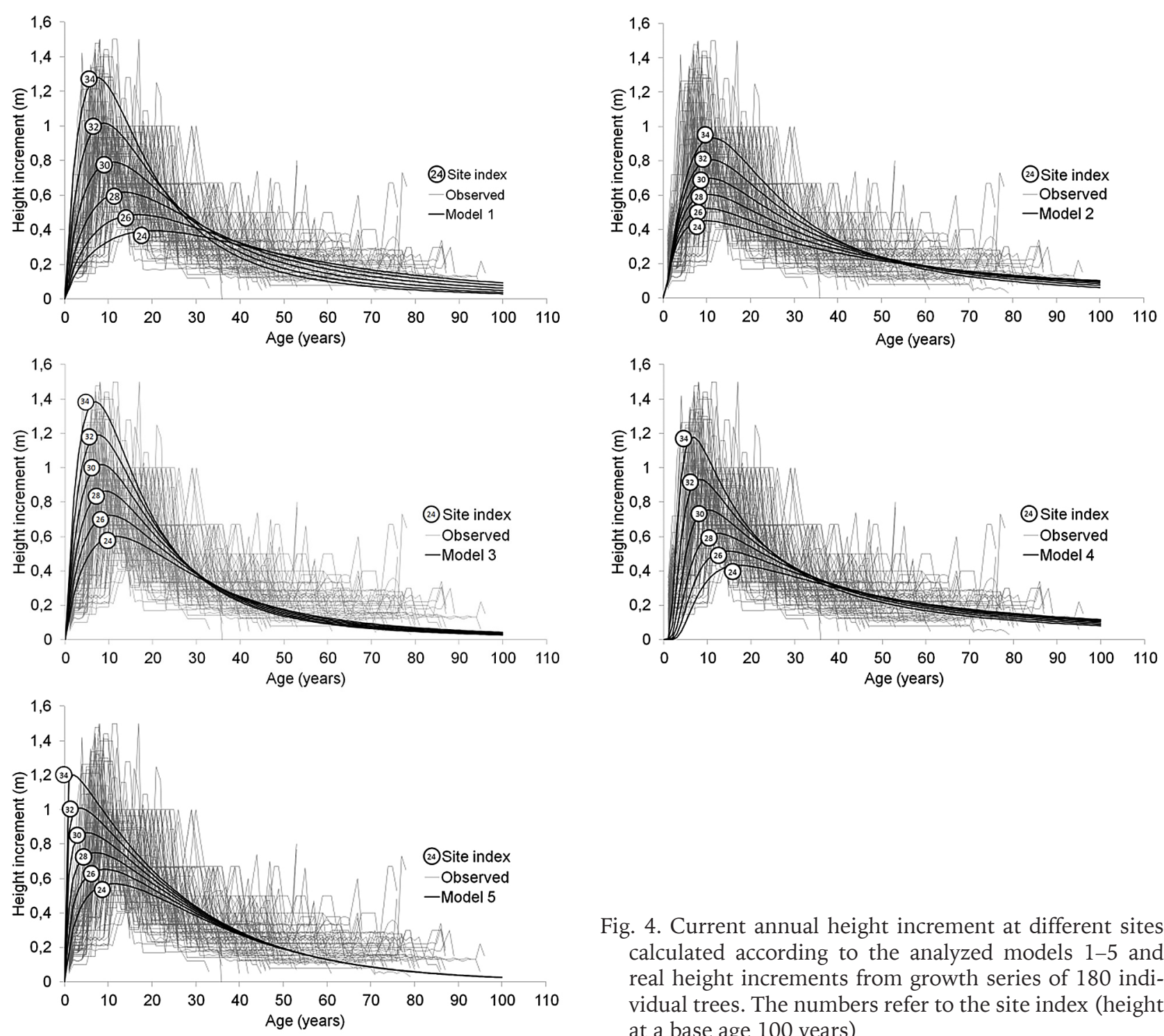

Fig. 4. Current annual height increment at different sites calculated according to the analyzed models $1-5$ and real height increments from growth series of 180 individual trees. The numbers refer to the site index (height at a base age 100 years)

found that the site index calculated for 12,968 alder stands from inventory database (www.bdl.lasy.gov. $\mathrm{pl}, 2015)$ was significantly correlated with the year of stand origin (Fig. 5). In this case, year of stand origin explained $40.5 \%$ of the site index variability. The observed correlation confirmed the existence of the phenomenon of increasing site productivity at the large scale. Site indices calculated for research plots were slightly larger than those observed in the whole population of black alder stands in Malopolska natural-forest region. The mean difference varied from $1.9 \mathrm{~m}$ in young stands originated in the last two decades to $2.6 \mathrm{~m}$ in older stands originated in 1920-1930. The mean difference between site indices of the stands established in 2000 and 1920 was equal to $4.1 \mathrm{~m}$ for research plots and $4.8 \mathrm{~m}$ for population of stands growing in Malopolska region; that means that during the last century, site productivity increased for black alder by over one site

class according yield Tables by Tiurin (Szymkiewicz, 2001) or Schwappach (1943).

\section{Discussion}

The research focused on detailed analysis of five solutions of site index models, which in previous works were selected as the best from among a dozen or so others. Some of them were used for the modeling of site indices of black alder stands (Nigh \& Courtin, 1998; Nigh \& Love, 1999). When selecting a model describing a site index, apart from the quality of fit, we also considered the compatibility of the resulting growth patterns to commonly known biological rules. The model form M4 developed from Korf growth function performed better than the other model forms. The M4 equation that fitted the best to the collected height growth trajectories was also be 


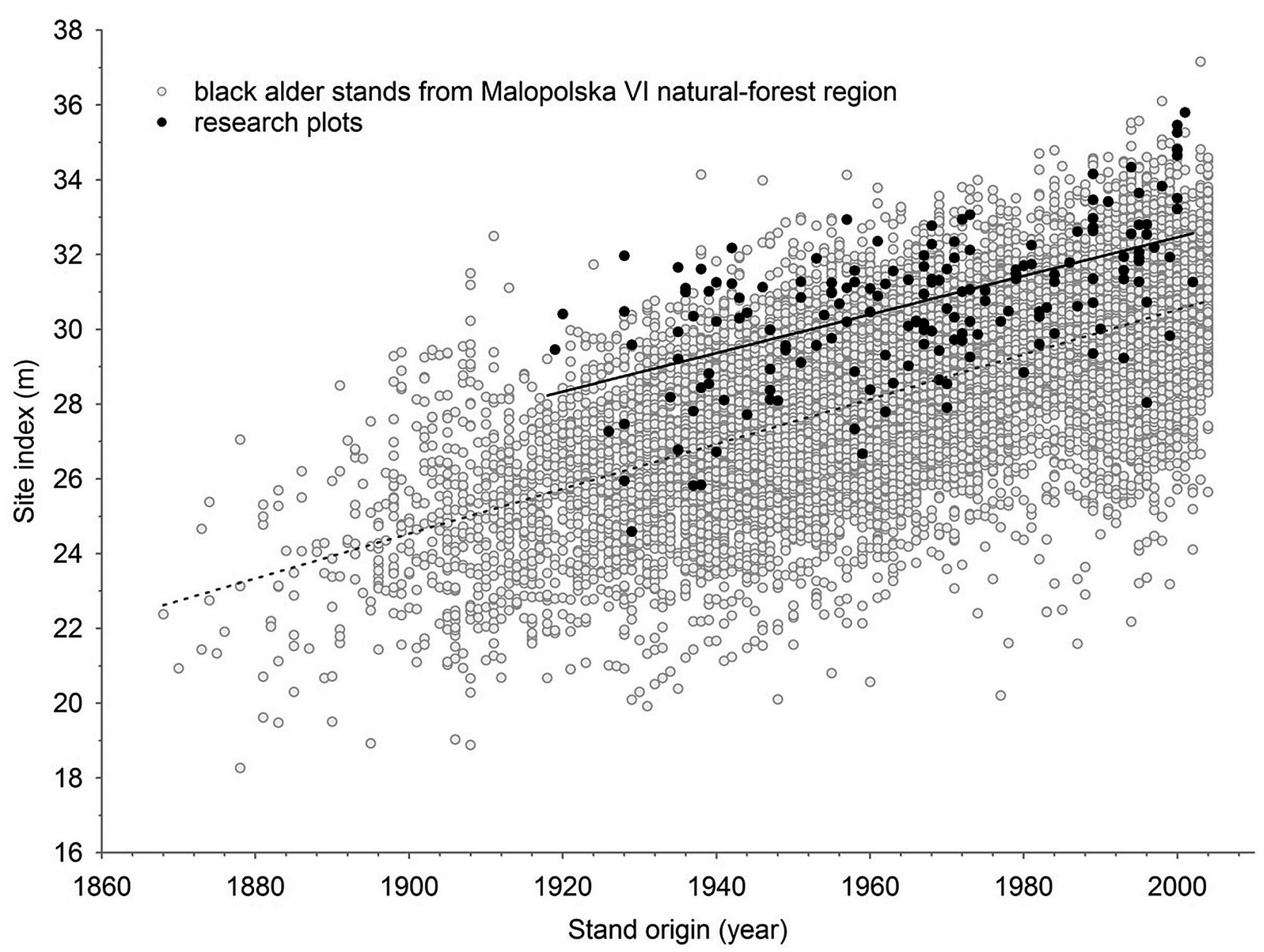

Fig. 5. Relationship between site index and stand origin (year) for research plots and black alder stands' population from Malopolska natural-forest region in Poland

reliable in the sense of biological realism, which was confirmed by the analysis of the current height increment (Bruchwald et al., 2001). In the selected model the current height growth culminates later with decreasing site productivity. In addition, for the entire age range, the current increment attains the higher value for higher the site index of the stand. The M3 model developed on the basis of functions derived by Nigh \& Courtin (1998) also meets the criterion for biological realism. However, the statistics describing model M3 fit to empirical data, and dispersion of residual values, are considerably less favorable in comparison with the M4 function. Similar statistical criteria were obtained for model M1. However, considering the plot of residual against predicted values and the course of height growth, the age of its culmination as well the unrealistic height increment in oldest stands, these models are less appropriate for the calculation of site index for black alder in southern Poland.

The Korf growth function developed by Barrio Anta \& Diéguez-Aranda (2005), which was selected to construct the site index model M4, is characterized by polymorphism, which had a crucial impact on its good fit to empirical data.

The developed site index model M4 shows different growth trajectories in comparison with site index curves for black alder acquired on the basis of yield Tables by Tiurin (Szymkiewicz, 2001) or Schwappach (1943) applied in forest management in Poland (Fig. 6). Also height growth curves from growth model developed earlier for black alder in Poland (Bruchwald et al., 2000) shows significantly different growth patterns in comparison with both the M4 model we developed and growth series obtained by stem analysis of sample trees (Fig. 6). In comparison with yield Tables by Schwappach, Tiurin, and Bruchwald's growth model, the developed M4 model gives lower height growth rates at younger stand ages (up to 30-40 years) and higher growth rates for older stands (Fig. 6). Largest discrepancies were found between the developed M4 model and the site index curves from Schwappach's (1943) yield Tables. These discrepancies can partly be explained by the different method of stand establishment. It is highly probable that fast growth at the first ages of the stand is caused by the fact that the stands used by Schwappach were 

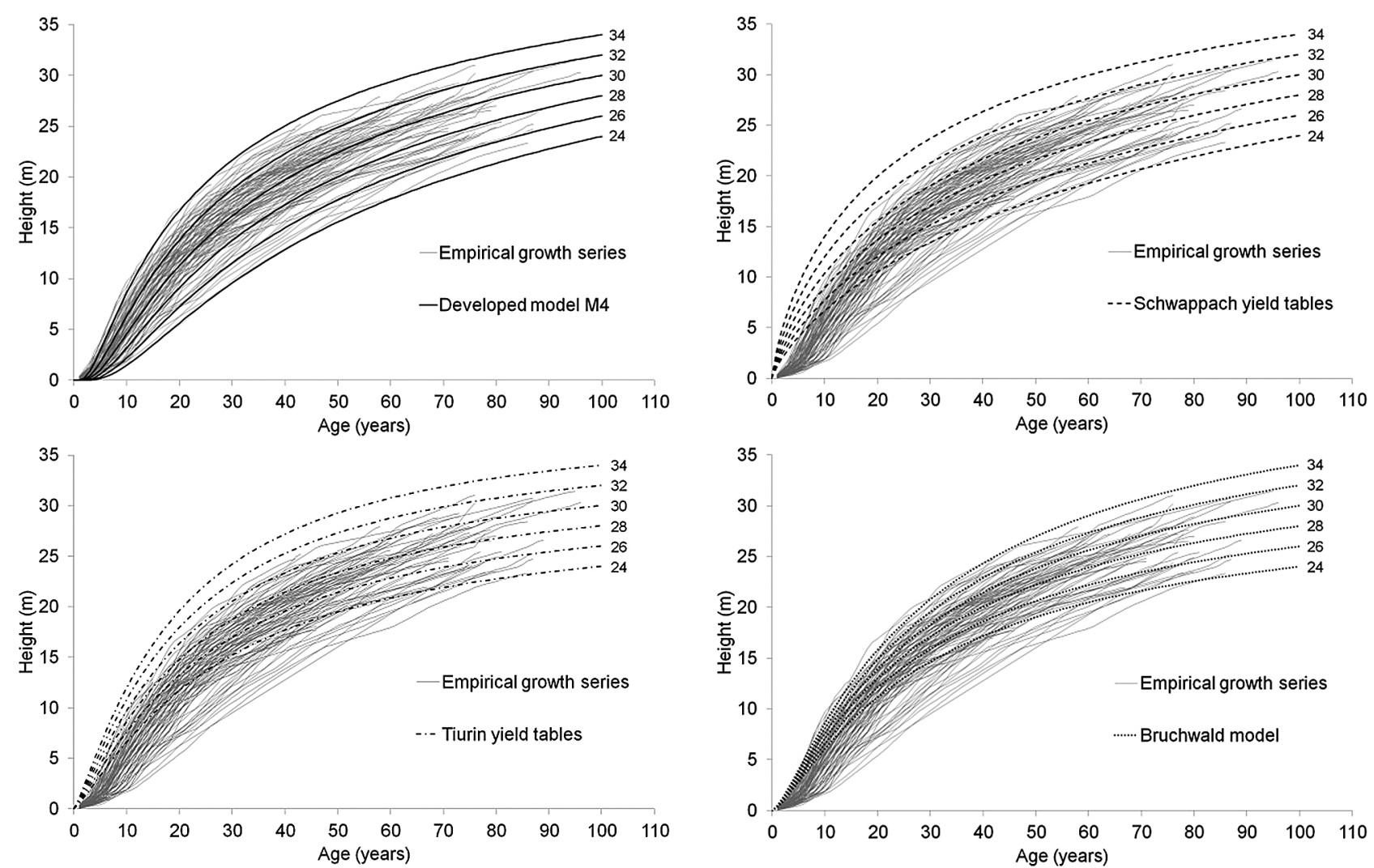

Fig. 6. Comparison of height growth curves as calculated on the basis of the elaborated site index model with the height growth curves obtained from Schwappach's yield Tables as well and Tiurin's yield Tables and Bruchwald's site index model

established by coppicing. Another cause of observed differences in height development patterns could be the origin of research material and the difference in site conditions of research plots used to develop both Schwappach's yield Tables and the M4 model for southern Poland. Other causes for the differences in growth dynamics of the stands older than 30-40 years are: site eutrophication, increased concentration of atmospheric $\mathrm{CO}_{2}$, and the change in climatic conditions, especially increased mean yearly temperature and resulting extended length of the vegetation period, which together caused substantial changes in site conditions during the last century, i.e., during the period from the development of Tiurin's and Schwappach's yield Tables. The other possible cause includes genetic improvement of seeds used for stands establishment by the selection of most productive populations. The difference between growth patterns of M4 model and Bruchwald (Bruchwald et al., 2003) model may be the effect of using Bruchwald's anamorphic function, which after calculation of parameters for mean height growth trajectory is scaled for upper and lower site indices. This probably resulted in a narrow range of expected heights for young stands and increasing range of heights for older stands, which is in contrast with empirical growth trajectories (Fig. 6).
Both in case of research plots and stands from Malopolska natural-forest region, the site index significantly correlates with the year of stand origin. This may be the result of improving site conditions for this species on analyzed area. In the case of deteriorating or improving site conditions such as brought about by fertilization, or nitrogen deposition, improved climatic conditions, increased $\mathrm{CO}_{2}$ concentration, genetic improvement and change in forest management practice or other factors influencing growth rate, younger stands may grow faster and therefore site indices for younger stands are different from site indices observed in case of older stands (Nothdurft et al., 2012; Yue et al., 2014). Therefore, probably the most observed phenomenon of age trend in the site index is the effect of continuous process of increasing site productivity for black alder in southern Poland. The comparison of site indices of stands originated in the second (younger than 65 years) and the first half (older than 65 years) of 20th century indicates the increasing dynamics of this process. In the first half of 20th century, an increase in site productivity for black alder stands was substantially slower than in the second. In the case of Norway spruce in Norway, comparable trends were obtained by Sharma et al. (2012), with the process of amelioration of site conditions also substantially faster in the second half of 
the 20th century. A similar trend was also observed in Estonia for height growth of Scots pine (Metslaid et al., 2011). The authors observed significant differences in height growth between generations of trees, stating faster growth of the younger generation of Scots pine trees.

Our results indicate the improving site conditions for growth of black alder stands in southern Poland. Increasing growth potential for black alder may point to growing importance of this species in forest management. However, increased growth dynamics could also be the source of problems. Growing nitrogen and $\mathrm{CO}_{2}$ concentration with longer vegetation period and higher mean yearly temperatures are among the factors accelerating increment of forest stands with reduced natural self-thinning, what may result in decreasing stand stability. As a result of this type of reaction, deficit of macro and microelements may occur in the soil, which may hamper the status of forest health. Fast growing and dense stands are also especially endangered by drought stress (Spiecker et al., 1996). Therefore, these aspects of changing site conditions should be acknowledged in forest management practice.

\section{Conclusion}

Giving the best representation of the empirical data and the reliability in the course of the height increment, the developed M4 site index model, which is based on Korf function, is recommended as the site index model for black alder in southern Poland. Elaborated model can be applied locally to black alder stands from Malopolska natural-forest region in Poland. It seems that in an era of large variability in climactic and site conditions, there exists a need for research on site-specific site index models, which take into account, apart from features of stands, the detailed information related to sites. Observed age trend in site index calculated both for collected research plots and the large database of black alder stands from southern Poland indicates the increasing site productivity for black alder over time. Therefore, black alder that belongs to the fast-growing tree species should be considered of the increasing importance for forest management. Factors ameliorating site conditions for growth of black alder will result in positive effects on forest growth and wood production; however, on the contrary, increasing drought and disturbance risks will cause adverse effects, which should be acknowledged in forest management practice.

\section{Acknowledgments}

This paper was written as part of research project BZ/ZBiPL/14-17 "Actual and potential site productivity for main forest forming tree species in Poland" and statutory research (DS-3418/ZBiPL/16) carried out at the Department of Biometry and Forest Productivity, University of Agriculture in Krakow. The research material was collected in the framework of a project funded by the Polish National Science Center, Grant N N309 160638. Comparative analyzes were performed on the data from Forest Data Bank (www.bdl.lasy.gov.pl).

\section{References}

Albert M \& Schmidt M (2010) Climate-sensitive modelling of site-productivity relationships for Norway spruce (Picea abies (L.) Karst.) and common beech (Fagus sylvatica L.). Forest Ecology and Management 259: 739-749. doi:10.1016/j.foreco.2009.04.039.

Barrio Anta M \& Diéguez-Aranda U (2005) Site Quality of pedunculate oak (Quercus robur L.) stands in Galicia (northwest Spain). European Journal of Forest Research 124: 19-28.

BDL, Forest Data Bank (2014) www.bdl.lasy.gov.pl.

Bontemps JD \& Bouriaud O (2013) Predictive approaches to forest site productivity: recent trends, challenges and future perspectives. Forestry 87: 109-128. doi:10.1093/forestry/cpt034.

Bruchwald A, Dmyterko E, Dudzińska M \& Wirowski M (2001) Analiza faz wzrostu wysokości olszy czarnej (Alnus glutinosa (L.) Gaertn.). Sylwan 145: 5-11.

Bruchwald A, Dudzińska M \& Wirowski M (2003) Model wzrostu dla olszy czarnej (Alnus glutinosa (L.) Gaertn.). Sylwan 147: 3-10.

Bruchwald A, Michalak K, Wróblewski L \& Zasada M (2000) Wzrost wysokości sosny w różnych regionach Polski: Przestrzenne zróżnicowanie wzrostu sosny. Fundacja Rozwoju SGGW, Warszawa, pp. 77-83.

Bruchwald A \& Zasada M (2010) Model wzrostu modrzewia europejskiego (Larix decidua Mill.). Sylwan 154: 615-624.

Carmean WH (1972) Site index curves for upland oaks in the Central States. Forest Science 18: 109-120.

Chen HYH, Klinka K \& Kabzems RD (1998) Site index, site quality, and foliar nutrients of trembling aspen: relationships and prediction. Canadian Journal of Forest Research 28: 1743-1755.

Cieszewski CJ, Harrison M \& Martin SW (2000) Practical methods for estimating non-biased pa- 
rameters in self-referencing growth and yield models. University of Georgia, PMRC-TR 2000-7.

Cieszewski CJ (2001) Three methods of deriving advanced dynamic site equations demonstrated on inland Douglas-fir site curves. Canadian Journal of Forest Research 31: 165-173.

Cieszewski CJ (2003) Developing a well-behaved dynamic site equation using a modified hossfeld IV function $\mathrm{Y} 3=(\mathrm{axm}) /(\mathrm{c}+\mathrm{x} \mathrm{m}-1)$, a simplified mixed-model and scant subalpine fir data. Forest Science 49: 539-554.

Cieszewski CJ \& Bailey L (2000) Generalized algebraic difference approach: Theory based derivation of dynamic site equations with polymorphism and variable asymptotes. Forest Science 46: 116-126.

Cieszewski CJ \& Zasada M (2003) Wyprowadzanie ogólnych dynamicznych równań bonitacyjnych za pomocą uniwersalnej metody różnic algebraicznych. Sylwan 147: 40-46.

Claessens H, Oosterbaan A, Savill P \& Rondeux J (2010) A review of the characteristics of black alder (Alnus glutinosa (L.) Gaertn.) and their implications for silvicultural practices. Forestry 83: 163-175. doi:10.1093/forestry/cpp038.

Elfving B \& Kiviste A (1997) Construction of site index equations for Pinus sylvestris L. using permanent plot data in Sweden. Forest Ecology and Management 98: 125-134.

Elfving B \& Tegnhammar L (1996) Trends of tree growth in Swedish forests 1953-1992: An analysis based on sample trees from the national forest inventory. Scandinavian Journal of Forest Research 11: 26-37. doi:10.1080/02827589609382909.

Glavac V (1972) Über höhenwuchsleistung und wachstungoptimum der schwarzerle auf vergleichbaren standorten in Nord-, Mittel- und Südeuropa. Schriftenreihe der Forstlichen Fakultät der Universität Göttingen 45: 61.

Hägglund B (1981) Evaluation of forest site productivity. Commonwealth Forest Bureau Forest Abstract Reviews 42: 515-527.

Hytönen J \& Saarsalmi A (2015) Biomass production of coppiced grey alder and the effect of fertilization. Silva Fennica 49: 1-16. doi:10.14214/ sf. 1260 .

Johansson T (1999) Site index curves for common alder and grey alder growing on different types of forest soil in Sweden. Scandinavian Journal of Forest Research 14: 441-453. doi:10.1080/02827589950154140.

Krzaklewski W, Pietrzykowski M \& Woś B (2012) Survival and growth of alders (Alnus glutinosa (L.) Gaertn. and Alnus incana (L.) Moench) on fly ash technosols at different substrate improvement. Ecological Engineering 49: 35-40. doi:10.1016/j. ecoleng.2012.08.026.
Metslaid S, Sims A, Kangur A, Hordo M, Jõgiste K, Kiviste A \& Hari P (2011) Growth patterns from different forest generations of Scots pine in Estonia. Journal of Forest Research 16: 237-243. doi:10.1007/s10310-011-0275-4.

Monserud RA (1984) Height growth and site index curves for inland Douglas-fir based on stem analysis data and forest habitat type. Forest Science 4: 943-965.

Nigh GD \& Courtin PJ (1998) Height models for Red Alder (Alnus rubra Bong.) in British Columbia. New Forests 16: 59-70. doi:10.1023/A:1006561502635.

Nigh GD \& Love BA (1999) A model for estimating juvenile height of lodgepole pine. Forest Ecology and Management 123: 157-166. doi:10.1016/ S0378-1127(99)00019-5.

Nord-Larsen T (2006) Developing dynamic site index curves for European beech (Fagus sylvatica L.) in Denmark. Forest Science 52: 173-181. doi:10.1080/02827580902795036.

Nord-Larsen T, Mielby H \& Skovsgaard JP (2009) Site-specific height growth models for six common tree species in Denmark. Scandinavian Journal of Forest Research 24: 194-204.

Nothdurft A, Wolf T, Ringeler A, Böhner J \& Saborowski J (2012) Spatio-temporal prediction of site index based on forest inventories and climate change scenarios. Forest Ecology and Management 279: 97-111. doi:10.1016/j.foreco.2012.05.018.

Palahí M, Tomé M, Pukkala T, Trasobares A \& Montero G (2004) Site index model for Pinus sylvestris in north-east Spain. Forest Ecology and Management 187: 35-47.

Payandeh B (1974) Formulated site index curves for major timber species in Ontario. Forest Science 20: $143-144$.

Pretzsch H (2009) Forest dynamics, growth and yield. From measurement to model. Springer Verlag, Berlin Heidelberg.

Pretzsch H, Biber P \& Dursky J (2002) The single tree-based stand simulator SILVA: construction, application and evaluation. Forest Ecology and Management 162: 3-21.

R DCT (2008) R: A language and environment for statistical computing. R Foundation for Statistical Computing, Vienna, Austria. ISBN 3-900051-070, http://www.R-project.org.

Raulier F, Lambert MC, Pothier D \& Ung CH (2003) Impact of dominant tree dynamics on site index curves. Forest Ecology and Management 184: 6578. doi:10.1016/S0378-1127(03)00149-X.

Roisin P \& Thill A (1972) Excursions forestières en Yougoslavie. Bulletin de la Société Royale de Forestière de Belgique 79: 109-164.

Schwappach A (1908) Die kiefer. Wirtschaftliche und statische untersuchungen der forstlichen abtei- 
lung der hauptstation des forstlichen versuchswechungens in Eberswalde. Verlag J. Neumann.

Schwappach A (1943) Ertragstafeln der wichtigeren Holzarten in tabellarischer und graphischer form. Verlag der Handelsdruckerei Merkur, Prag.

Sharma RP, Brunner A \& Eid T (2012) Site index prediction from site and climate variables for Norway spruce and Scots pine in Norway. Scandinavian Journal of Forest Research 27: 619-636. doi:10.1 080/02827581.2012.685749.

Skovsgaard JP \& Vanclay JK (2008) Forest site productivity: a review of the evolution of dendrometric concepts for even-aged stands. Forestry 81: 13-31. doi:10.1093/forestry/cpm041.

Socha J (2008) Effect of topography and geology on the site index of Picea abies in the West Carpathian, Poland. Scandinavian Journal of Forest Research 23: 203-213.

Socha J, Coops N \& Ochał W (2016) Assessment of age bias in site index equations. iForest - Biogeosciences and Forestry 9: 402-408. doi:10.3832/ ifor 1548-008.

Socha J, Ochał W, Grabczyński S \& Maj M (2015) Modele bonitacyjne dla gatunków lasotwórczych Polski opracowane na podstawie tablic zasobności. Sylwan 159: 639-649.

Socha J \& Orzeł S (2013) Dynamiczne krzywe bonitacyjne dla sosny zwyczajnej (Pinus sylvestris L.) z poludniowej Polski. Sylwan 157: 26-38.

Solberg S, Dobbertin M, Reinds GJ, Lange H, Andreassen K, Fernandez PG, Hildingsson A \& de Vries W (2009) Analyses of the impact of changes in atmospheric deposition and climate on forest growth in European monitoring plots: A stand growth approach. Forest Ecology and Management 258: 1735-1750. doi:10.1016/j.foreco.2008.09.057.

Spiecker H, Mielikäinen K, Köhl M \& Skovsgaard JP (1996) Growth trends in European forests. Springer Berlin Heidelberg, Berlin, Heidelberg. doi:10.1007/978-3-642-61178-0.

Splechtna BE (2001) Height growth and site index models for Pacific silver fir in southwestern
British Columbia. BC Journal of Ecosystems and Management 1: 1-14.

Szymkiewicz B (2001) Tablice zasobności i przyrostu drzewostanów. Państwowe Wydawnictwo Rolnicze i Leśne, Warszawa.

Tegnhammar L (1992) On the estimation of site index for Norway spruce. Department of Forest Survey, Swedish University of Agricultural Sciences. Report 53, 259.

Thibaut A, Claessens H \& Rondeux J (2004) Site index curves for Alnus glutinosa (L.) Gaertn. in southern Belgium: effect of site on curve shape. Forestry 77: 157-171. doi:10.1093/forestry/77.2.157

Thill A \& Mathy P (1980) La culture des essences précieuses en Belgique. Annales de Gembloux 86: $1-32$.

Turok J, Erikson G, Kleinschmit J \& Canger S (1996) Noble hardwoods network. Report of the first meeting, International Plant Genetic Resources Institute, Rome, Italy.

Uri V, Aosaar J, Varik M, Becker H, Ligi K, Padari A, Kanal A \& Lõhmus K (2014) The dynamics of biomass production, carbon and nitrogen accumulation in grey alder (Alnus incana (L.) Moench) chronosequence stands in Estonia. Forest Ecology and Management 327: 106-117. doi:10.1016/j. foreco.2014.04.040.

Vacek Z, Vacek S, Podrázský V, Král J, Bulušek D, Putalová T, Baláš M \& Kalousková I (2016) Structural diversity and production of alder stands on former agricultural land at high altitudes. Dedrobiology 75: 31-44.

Yue C, Mäkinen H, Klädtke J \& Kohnle U (2014) An approach to assessing site index changes of Norway spruce based on spatially and temporally disjunct measurement series. Forest Ecology and Management 323: 10-19. doi:10.1016/j.foreco.2014.03.031.

Zasada M (2002) Określanie bonitacji za pomocą młodocianego przyrostu wysokości w drzewostanach sosnowych. Sylwan 146: 21-29. 